\title{
CLIMATE VARIATION-INDUCED MIGRATION, LAND CONFLICTS, AND SECURITY SITUATION IN NIGERIA
}

\author{
DICKSON OGBONNAYA IGWE*
}

\begin{abstract}
Climate variation largely impacts migration in with the capacity to worsen conflict and security situations in parts of Africa, Nigeria in particularly, already facing security threats from the activities of sedentary and nomadic pastoral farmer's interaction. Increasing variations in rainfall patterns significantly impact the migration patterns of vulnerable households and constitute a risk factor to their livelihoods. For effective adaptation plan and sustainable livelihood decision that has climate resilient future, there is need for better understanding of the conflict and security implications of climate variation. This paper, therefore, interrogates the nexus between climate variation and migration, as well as the impact of this nexus on conflicts and security of lives and properties in Nigeria. Using critical analysis and qualitative methodology, the study establishes that migration settlement policies that fail to define the rights and duties of settlers and those of indigenes of any particular community, create loopholes for the reification of identities and identity-induced crisis. The conclusion of the paper is that migration issues resulting from climate variation have not been adequately addressed to involve all stakeholders. There is the need to harvest environmental impact assessment data of climate variation to guide the provision of alternative options to climate-related emergencies across Nigeria.
\end{abstract}

Key Words: Conflict, Security, Climate variation, Migration, Nigeria

Summary: 1. Introduction. 2. Theoretical conceptualisation of migration. 3. Effects of Climate Variation and Migration. 4. Agrarian Production and Security Challenges. 5. Climate Variation-Induced Migration, Land Conflict and Security. 6. Some Major Land-Related Conflicts in Nigeria. 7. Migration experience between Ezillo and Ezza People. 8. Seasonal migration and security Questions in Nigeria. 9. Conclusion.

\section{INTRODUCTION}

Most recently, climate change in Africa has generated recurrent conflicts that encouraged increased wave of migration both within and outside of the continent. Among these are the protracted Somali insurrection, civil war in southern Sudan, Boko Harram insurgency in Nigeria, Chad, Niger and Cameroon, and the crisis in the Democratic Republic of Congo (DRC), the Darfur crisis, Somalia crisis and a series of boundary clashes among many others. Several other natural occurrences particularly famine and drought have occasioned mass displacement of people and family dislocation. The result of absence of social support need for survival directly generate frustration, aggression and ultimately involvement in social vices such as crime. Consequently, migration in search for alternative favourable location exposes migrants to contact people settled at

\footnotetext{
* (B.Sc. Sociology, Dip. Criminal Justice Admin. \& M.Sc. Criminology, UNILAG); Dip. Peace and Conflict Resolution, Chula. Bangkok, Thailand; M.Phil. Criminology \& Ph.D. Criminology and Development, UI). University Lecturer, Department of Criminology and Security Studies, Faculty of the Social Sciences, National Open University of Nigeria, 91 Cadastral Avenue, Nnamdi Azikiwe Way, Jabi-Abuja Nigeria, and Email: princedxn2010@hotmail.com.
} 
the receiving community. The problems of climate change-induced migration bring such group as herders/farmers into contact and clash of interest intensifying poverty. All these have combined with bad leadership to further accelerate the rate at which Africans migrate in crowds to different parts of the world. As it were, Africa seems to account for the majority of the total global conflicts. Kofi Annan, in his report to the United Nations Security Council (UNSC) titled: 'The causes of conflict and the promotion of durable peace and sustainable development in Africa,' noted that, '[...] 14 of the continent's 53 countries were afflicted by mostly climate change-induced migration and armed conflicts in 1996 alone, and over 30 wars have occurred... since 1970, mostly within states. These accounted for more than half of all the war-related deaths worldwide[...]". ${ }^{1}$

In the Nigerian context, climate change-induced migration generates land conflict posing global, regional, and national security challenges. Nigeria's economy is largely oil based. She always has to face issues about degradation and pollution, which are associated with oil exploration. The consequent carbon emission, gas flaring, and the pollutioninduced threat to marine life, significantly contribute to climate change and migration. The movement of both nomadic and sedentary farmers in search of better life and arable land to graze and farm constitutes climate change-induced migration. The contact among these farmers, and their disagreements over arable land spaces, generate conflicts.

These situations have led to violent death of persons and destruction of properties, in both rural and urban communities. Land conflict issues vary from region to region and community to community but of major concern to this paper, are the recurring conflicts in both the northern and southern regions of Nigeria between sedentary and nomadic farmers. The seasonal disparity in rainfall rate between these two regions is responsible for the variation in climate and vegetation. These seasonal variances bring to contact sedentary farmers in the south and herders from the north who move southward in search of water and vegetation to feed their livestock. Farmers-herders clashes are also evident in northern parts where integrated farming system is in operation, with the use of irrigation to ensure all year-round farming intensification between and within communities. The result is usually struggles by herders and farmers over land spaces for grazing and agricultural intensification, respectively. ${ }^{2}$ Studies in this direction are imperative because these clashes constitute threats to agricultural production, security of lives and properties, and food security.

This paper examined conflict and security effects of climate variation and migration in Nigeria. The paper is divided into nine sections: Theoretical Conceptualisation of Forced Migration, Effects of Climate Variation and Migration, Agrarian Production and Security Challenges, Forced Migration, Land Conflict and Security, Some Major Land Conflict in Nigeria, Migration-induced Recurrent Intermittent Intractable Conflict and

\footnotetext{
${ }^{1}$ Aboagye, F. B. 2009. Confronting complex emergencies in Africa: Imperatives of a search for a new doctrine of humanitarian 'security' interventions. ISS Paper 24, November. Pretoria: Institute for Security Studies (ISS), p.1

${ }^{2}$ Olajide O. Akanji 2012. Migration, Conflicts and Statehood Problem in Nigeria: the Self-determination Issue, Journal of Nigeria Studies, Volume 1, Number 2, p: 4-61.
} 
Insecurity between Ezillo and Ezza, Seasonal Migration and the Security Questions in Nigeria, conclusion and recommendations.

\section{THEORETICAL CONCEPTUALISATION OF MIGRATION}

The Rationalization theory according to Max Weber (1968) posits that a particular process is desirable because of the rational sense and value derivable from it. In the context of Climate Variation-Induced Migration, Land Conflicts, and Security Situation in Nigeria, there is often great difficulty, amongst people, to understand the logic of pastoralism. It was Ibrahim ${ }^{3}$ who drew attention to the popular adage in the popular imagination that, 'nomads' are conceived of as wandering from place to place without any logic. What is better understood is the culture of farming, which is rooted in a specific location and has activities that take place regularly. This lack of understanding of the culture of pastoralism makes people susceptible to subjecting its practitioners easily to the subject of innuendos and aspersions, accused of robbery, cattle rustling, rape, kidnapping and even scorched earth policy. The greatest problem associated with such misunderstanding is assuming that pastoralism is in itself an irrational production system, which is far from the truth. Pastoralism can be categorised into nomadic, transhumance or agro-pastoralist forms based on the degree of movement.

Transhumance pastoralism, which involves the regular movement of herds between fixed points to exploit seasonal availability of pasture, is the most misunderstood. This mode of production involves sending part or all of the herd to access crop residue in adjacent farms or graze in open range and in some cases even move further southwards as the dry season becomes more severe and returning home (North) with the advent of the rains. Transhumance pastoralism is an enduring form of livestock production involving seasonal and cyclical migration between complementary ecological zones which is today under threat in west and central Africa. Pastoralism is the main livestock production system in much of Africa where pastoralists live in semi-arid zones. It is a historically developed strategy to cope with the uncertainties associated with climate change, epizootics, buildup of parasites and other related challenges. It is above all an efficient way to produce livestock at relatively low prices through the use of non-commercial feeding stock.

\section{Effects of Climate Variation and Migration}

Two main causal factors explain climate variation and migration: natural and human activities. Increasing population, industrialisation, and agricultural intensification, are major human factors that aggravate the impacts of natural process of climate variations on people's livelihood and survival needs. ${ }^{4}$ Before now, changes in the earth's orbit, solar activities, and volcanic eruptions had no significant impacts on humans as they do today. Various human activities including deforestation, burning of fossil fuels for industries and

\footnotetext{
${ }^{3}$ Ibrahim, Jubril, 2019. Transhumance, Pastoralism and Citizenship Crisis in West Africa, in Augustine, I.; Abdulwahab, M. \& Karim, A. Ed. Transhumance and International Migration: Challenges for Governance, Peace and Sustainable Development in Sub-Saharan Africa, National Institute for Security, Abuja.

${ }^{4}$ FM Brookfield 1992. Treaties and Indigenous Peoples. The Robb lectures. Oxford: Clarendon Press.
} 
transport, gas flaring, water and air pollution, urbanization, infrastructural development that are associated with industrialisation, account for about $80 \%$ of climate variation ${ }^{5}$ Consequently, more than ever before, there are recurrent cases of severe heat waves, drought, flood, increased health risks, rising sea levels, and other negative impacts. The components of greenhouse gas are water vapour, carbon dioxide, nitrous oxide and methane that obstruct the loss of heat from the earth keeping it warmer and hot. The trapping of heat and obstruction of its escape from the earth increase the stress and vulnerability, of human population, environment and economy.

In recent migration policy discourse, the linkages between climate variation and migration effect on security challenges, especially violent extremism have been highlighted. The 2018 World Migration Report identifies five-fold typology of the effects of climate variation and migration looking at them from their security implications such as violent extremism, in transit and destination countries/communities namely:

Violent extremism as a driver for displacement and migration, like the population displaced in northern Nigeria as a result of the deliberate attacks of Boko Haram; The risk of radicalization in refugee, IDP and possibly transit camps, where such camps may serve as bases for fighters to rest, and also serve as recruitment group's ground, like the Minawao Camp in northern Cameroun which risk becoming a recruitment base for Boko Haram; ${ }^{6}$ The risk of terrorist infiltration of migration and asylum flows, as suspected of ISIS members from Syrian Arab Republic and Iraq via Turkey into Europe; ${ }^{7}$ The migrants' challenges of integration resulting in social exclusion, and unequal power relations through access to resources, capabilities and lights; ${ }^{8,9}$ and migrant's returnees facing unsustainable reintegration processes leading to aggressive tendencies and aversion to social norms. Similarly, increased temperatures and rainfall variability significantly affect food production, water supply and resources, biodiversity, and human and animal populations. So long as migration pattern and decision reflect climate variation and human activities continue to accelerate the debilitating impacts of climate variation on human population, environment and economy, conflict and security pattern and threat.

\section{Agrarian Production and Security Challenges}

Provision of the basic need for food/feed, fibre, and energy is the primary purpose of agriculture. Agrarian life is a support to subsistent agricultural production. Research shows that nearly $70 \%$ of people in developing countries are agrarian and are largely

\footnotetext{
${ }^{5}$ Cabot, C., 2017. Climate Change, Security Risks and Conflict Reduction in Africa, Hexagon Series on Human and Environmental Security and Peace.

${ }^{6}$ Larson, N. 2015. UN Condemns Boko Hara abuse of children in Cameroon, AFP, 4 June (www.capitalfin. co.ke/news/2015).

${ }^{7}$ Rudiger, A. and Spencer, S. 2003. The Economic and OECD (www.oecd.org/miration).

${ }^{8}$ Schmid, A. 2016. Link between Terrorism and Migration: an Exploration; International Centre for Countries Terrorism - The Hague (hhps://:cct.nl/publication/links).

${ }^{9}$ UNDESA, 2016. Leaving No One Behind: Counting all People Because All of Them Count, United National Department Economic and Social Affairs (www.un.org/development/desa).
} 
involved in agricultural activities for livelihood and survival. ${ }^{10}$ The implication is that climatic variation should not be an isolated discussion but a global one since it affects majority of the people and puts at stake the livelihood security and survival of most people in rural communities.

Temperature, radiation, precipitation, and humidity, among others, have direct impacts on agricultural production including forestry, vegetation and fishery systems, as the atmospheric conditions determine vegetative growth and animal production. For instance, given a projected agricultural production decrease for small temperature increase of about $1-6^{\circ} \mathrm{C}$ in an area: on the other hand, changes in cool regions has the potential to increase food production even when local average temperature rises over an range of $1-7^{\circ} \mathrm{C} .{ }^{11}$ This is a clear indication of regional differentials in climatic temperature and agricultural production. It influences the migration decision people take for survival since they move in response to weather/seasonal variations, to places with favourable climatic conditions for agricultural production. To avert poor yields or crop failure, investment plans are not done without climate variation impact assessment. Unfortunately, sometimes, possible conflicts and the security implications of investment and migration decisions are not taken into proper account.

\section{Climate Variation-Induced Migration, Land Conflict and Security}

There is an entwined relationship between climate variation, forced migration, land conflict, and security. Before now, the chad basin was home to many Nigerian and Chadian sedentary and pastoral farmers. But with the shrinking of the lake, many fish farmers lost their jobs to join pastoral or sedentary farming involving vegetation and land cultivation. This created new need for farm land both for farming and grazing of livestock putting pressure on earlier farmer to struggle for land access and denial. The migration from Lake Chad coast to the hinterland confronted the nomadic and sedentary farmers who were first settler in those areas. Hence, the struggle for access to land, its use and territorial authority to own land. The speed at which desertification is encroaching the Sahel and Savanna Regions of Northern Africa is exacerbating regional, national and local tensions in these 'hot-zones'.

The effects of climate variation have been interpreted from various dimensions. For instance, climate variation indirectly has drawn a parallel line of conflict in Nigeria between the Boko Haram and the Christian inhabitants of northern Nigeria just as it has sown the seed of animosity and fear between nomadic pastoralists and sedentary farmers both in northern and southern Nigeria. In almost all cases, the issue of contention is green vegetation and farmland for farming and grazing. Beyond the activities of these insurgents migrating from hostile desert to displace people in Sahel, Savannah and

\footnotetext{
${ }^{10}$ IPCC 2007. Climate Change 2007. Impact, Adaptation, and Vulnerability. Working Group II Contribution to the Intergovernmental Panel on Climate Change Fourth Assessment Report UNEP (2011): Livelihood Security. Climate Change, Migration and Conflict in the Sahel.

${ }^{11}$ Cabot, C., 2017. Climate Change, Security Risks and Conflict Reduction in Africa, Hexagon Series on Human and Environmental Security and Peace, 12.
} 
Mangrove areas, is the issue of population. Demographic pressure created by mass movement human and animal from the northern part of Nigeria to the southern part lead to displacement and humanitarian issues that trigger up conflict between the migrants and their host communities. As access to farmland for farming become scarce, too many hands contest access and use of land for livelihood and economic survival, but given the limited land access and the need for food and survival, actors resort to violent search for land. ${ }^{12}$

\section{Some Major Land-Related Conflicts in Nigeria}

Discussion of conflicts in Nigeria is not complete without reference to pre-colonial struggles for land spaces between ethnic groups. However, to a large extent, most modern issues of access to, use and ownership of land have direct bearing on the British colonial establishment and the creation of administrative boundaries that did not reflect cultural and ethnic divisions. In 1914, northern and southern Nigeria was amalgamated. Each region carved out had a dominant ethnic group receiving the influx of people from minority groups. By the British design, the Emirs persuaded Igbo and Yoruba people to live in separate parts of northern cities in a reserved area known as sabon-gari, or stranger's quarters, just to avoid clash of culture. ${ }^{13}$ The British stimulated inter-group relations and competition, and mobilised people in a manner that consolidated their hold on political power and land resources. This last component of their later set the stage for decades of conflicts in Nigeria.

Generally, in Africa and Nigeria in particular, land is communally owned. Communal ownership of land was short-lived with the advent of the colonial masters. The British introduced land reforms that almost wiped away the communal content of the indigenous land tenure system. Consequently, land issues became a leading cause of conflicts in Nigeria. The migrant peasant land investors were no less different from the indigenous land owners. Identity and authority over land became issues of contestation for both first settlers and subsequent settlers in communities. Access to land is important to poverty reduction, economic growth, and the empowerment of the poor. ${ }^{14}$ This underscores territorial expansion as a solution to climatic variations. It does also justify perhaps why land conflicts are so prevalent, and why they are more difficult to solve than other conflict issues. ${ }^{15}$ Nigeria has experienced many decades of land conflicts, and the number of people

\footnotetext{
12 Odoh, S. I., and Chilaka Francis Chigozie 2012. "Climate change and conflict in Nigeria: a theoretical and empirical examination of the worsening incidence of conflict between Fulani Herdsmen and farmers in northern Nigeria." Arabian Journal of Business and Management Review: at 121.

${ }^{13}$ Osaghae, Eghosa E., and Rotimi T. Suberu. 2005. A history of identities, violence and stability in Nigeria. Centre for Research on Inequality, Human Security and Ethnicity, University of Oxford.

${ }^{14}$ Fabusoro, E., T. Matsumoto, and M. Taeb. 2008. "Land rights regimes in southwest Nigeria: implications for land access and livelihoods security of settled Fulani agro pastoralists." Land Degradation \& Development, Volume 19, Number 1, pp. 91-103.

${ }^{15}$ Olabode, A. D., and L. T. Ajibade. 2010 "Environment Induced Conflict and Sustainable Development: A Case Of Fulani-Farmers' Conflict In Oke-Ero LGAs, Kwara State, Nigeria." Journal of Sustainable Development in Africa, Volume 12, Number 5, pp. 259-2743, at 263.
} 
dying as a result continues to grow each year. Some of these conflicts include the Ife/ Modakeke, the Agulere/Umulere, the Tiv/Jukun, and the Ezillo and Ezza land conflicts. ${ }^{16}$

\section{Migration experience between Ezillo and Ezza People}

The search for farm land and territorial space to exert power and authority are factors central to the understanding of the conflict and security threat associated with migration within and around Ezillo community. The conflicts usually involve indigenous Ezillo people and Ezza migrants. Majority of Ezza migrants are farmers who are known for the cultivation and trade in yam, cassava, and rice. Unlike rice which is cultivated at the pick of the rainy season, yam and cassava are cultivated at the beginning of the rainy season. The hoeing skills of most Ezza people are widely acclaimed. They migrate from place to place in search of land to farm and farmers to buy their farm labour. The seasonal influx of Ezza migrant labourers into Ezillo community usually overwhelms available space for farming and habitation. Ezillo and Ezza land conflicts date back to 1930s during the colonial regime whose interventions could not stop the conflicts. ${ }^{17}$ While the indigenous land owners (Ezillos) exercise authority over their land, the land investors and settlers (Ezza) insist on their right to land both as compensation for assisting Ezillos to prosecute war of recovery from invasion, and as a property purchase from Ezillos. An interviewee from Ezillo says:

Ezillo people reject domination based on shared kinship arising from reinvention by Ezza people the exercise of their ancient ancestral authority in Ezillo community. The Ezzas in Ezillo are migrant settlers in this community and has no authority to exercise outside Ezillo traditional authority. To allow the exercise of parallel authority by anybody amount to confusion, anarchy and internal enslavement and colonisation. So, it is not acceptable to us despite exchange we have had together. ${ }^{18}$

\section{An interviewee from Ezza says:}

The entire northeast Igboland (NEI) was a territory that discovered by a progenitor Ekumaenyi Ezekuna who according to custom, exited passing on his authority over the region to his first son Ezza Ezekuna. While other two younger brothers of Ezza multiplied into places like Ezillo community, Ezza also increased in population and power to conquer and bring together his kindred including those from his other brothers Izzi and Ikwo. It is our birth right it is not given but inherited. We will resist any opposition to this order. Ezza ancestral mandate is to unit, secure and develop the culture and people of the ancient northeast Igboland. ${ }^{19}$

\footnotetext{
${ }^{16}$ Igwe, D. O. 2019. The Social Context of Ezilo and Ezza land Conflict in Ezillo Community, Ebonyi State South-East Nigeria; Unpublished thesis.

${ }^{17}$ Ibid

${ }^{18} \mathrm{KII} /$ Ezillo/Male lawyer and Youth leader/ 45 years old/ $23^{\text {th }}$ July 2016.

${ }^{19}$ FGD/Ezza/Male Retiree, elderly man /62 years old and above/ $12^{\text {th }}$ August 2016.
} 
Data above show that Ezillo people reject being subject to any other authority than the Ezillo traditional authority as part of NEI territory. It suggests that Ezza prefers in Ezillo community existence of parallel exercise of authority that will enable them exercise ancestral authority alongside indigenous traditional Ezillo authority. The aggressive migration and occupation of land by Ezza within this area seem to affirm their preference. Also, the continuous contestation over land between Ezza and other groups in the area seem to mean their outright opposition to Ezza rulership over NEI. Despite this opposition, Ezza people still migrate to and reside freely in Ezillo.

Ezillos suspicion of Ezza is anchored on the perceived offensive tendencies of Ezza people such as expansionist and colonisation tendencies, domineering and oppressive tendencies among others as described by (Brayne-Baker's Intelligence Report, 1936:67). The colonial administration attests to this migration, exchange and interaction. An archival record of Ogoja Provincial Annual Report, 1911:551 says:

[...]during the past ten years preceding the arrival of colonial authority in Ezillo area, there has been considerable influx of the virile and land hungry Ezza tribe into Ezillo. Based on good will and in return for appropriate presents and labour, these immigrants are allotted specific portions of Ezillo land for farming and residence. On the other hand, other villages of Ezillo area are as follows: Nkalagu, Iyono, Amezu, Umuhuale, Nkalaha, Obeagu and Obeagu Ezza.

While Ezza migrant farmers were used by Ezillo farmers on their farms, the labourers were also interested in exploring new areas to settle down for farming. These were the target and needs that characterised the first contact of Ezillo and Ezza. In order to meet the target of farm settlement, the needs for farm labour by their host Ezillo had to be satisfied. There was the emergence of a platform for reciprocal exchange of farmland and farm labour. The platform evolved into a very strong goodwill and mutual trust that metamorphosed into inter-marriage relations between Ezillo and Ezza. As their population increased, Ezza-Ezillo identity gained relevance, leading to self-consciousness. Request for land allocation became legitimate based on inheritance by birth. Several conflicts that fed from authority contentions are referred by an interviewee from Ezillo thus:

The Ezza people forcefully exercise authority they do not have as strangers in Ezillo as demonstration of their expansionist tendency. The offsprings of the invited and uninvited Ezza who settled earlier in Ezillo (identified as Ezza-Ezillo people) are presently claiming indigenous right $\mathrm{s}$ to land and other aboriginal entitlement which was not part of the original understanding reach before settlements were given to their forefathers. It won't come as a surprise if we lose our Ezillo identity to Ezza people whose population increase is already a threat. Example, in 1990, after the creation of Ishielu LGA with Ezillo as headquarters and land was allocated for secretariat office buildings; Ezza people went and occupied the entire land claiming ownership and compensation. In 1992, conflict resulted from contention over the seizure and renaming of Nwafor Isimkpuma Ezillo 
market to 'Eke Ezza' by the Ezza people. In 2006, refusal of Ezillo people to support the creation of Izzo autonomous community from Ezillo ignited serious contentions and conflict. Animosity over this led to Ezza assaulting the traditional ruler of Ezillo in the market square. In May 2008, collection of rent from users of motor park market in Isimkpuma led to disagreement as the Ezillo people refuse to pay the rent to the Ezza tax collector. These are instances of Ezza threat to rights to indigeneity as Ezillo people. ${ }^{20}$

\section{A KII from Ezza says:}

Ezza is no stranger anywhere in the entire NEI. The attempt by Ezillo to reconstruct history is unfortunate. Particularly the protest against our given authority over land acquired and allocated to Ezza by both the government of Ebonyi State and the people of Ezillo as permanent compensation for the mercenary service we rendered to Ezillo people. Our ancient ancestral kinship traditional authority encouraged inter-group interaction in NEI including Ezillo. In Ezillo, we got land right from Ezillo as compensation for military service we rendered to them. Also, we have worked hard and acquired land in Ezillo in addition to the additional potion of land the state gave us right to own. Our taking charge and exercising authority over Ezza legitimately owned land in Ezillo is not misplacement. As citizens of Nigeria we are also permitted by law to own land and live anywhere in Nigeria. Ezillo is looking for trouble. ${ }^{21}$

Data above reveals Ezza in Ezillo community violation of indigenous authority with impunity and incessant claim of rights to land at the displeasure of Ezillo people. Deconstruction of Ezillo indigenous authority by Ezza starts with several violation of land treaty that infringe on Ezillo rights to land and identity. The data show that Ezza already have offspring in Ezillo community with distinct Ezza-Ezillo identity. They are offspring from uninvited Ezza who settled earlier in Ezillo and the invited ones. Worrisome to Ezillo is the cloning of its identity by strangers otherwise known as Ezza settlers earlier presently constitute indigenes claiming indigenous rights to land and other aboriginal entitlement. On the other hand, the Ezza aside the ancestral right to land in NEI, is confidence that they have got rights to land allocated to her as compensation for the mercenary service they (Ezza) rendered to Ezillo and subsequent protection their presence in Ezillo portends to Ezillo community and people. Also, Ezza further argued that her members have at different time purchased land from Ezillo land owners that cannot be denied nor taken away from them.

The Ezza, therefore wondered what it is that Ezza is doing that is not part of the original understanding reach before settlements were given to the Ezza people in Ezillo. Apart from the various ways these authority sources have been reconstructed within intergenerational space, questions around statutory/citizenship rights, indigeneity rights, and settlers' rights, remain major issues of contestations. Incidentally, the Nigerian

\footnotetext{
${ }^{20} \mathrm{KII} / \mathrm{Male} / 67$ years old /Political office holder/ Ezillo/29 ${ }^{\text {th }}$ July 2016.

${ }^{21} \mathrm{IDI} / \mathrm{Men} /$ town union member $/ 64$ years $/$ Ezillo/17 $7^{\text {th }}$ August 2016.
} 
constitution is silent on these rights except that of citizenship. Thus, this has created space for ambiguity, contestations and conflict. ${ }^{22}$

Unlike the citizenship rights and entitlements, the ambiguity of indigene/settler rights and entitlements in the Nigerian constitution has left many groups fighting over the absence of definition of who is indigene and who is a settler. This has deepened rivalry and discrimination among groups in Nigeria. Drawing from this situation is the issue of land question that has remained unanswered in postcolonial Nigeria bedeviling our collective sensibility as a nation. However, the battle over indigenous authority and land rights in South-East Nigeria, particularly Ezillo, are mostly centered on indigene/settler entitlement question. Conflicts usually trigger when investors, otherwise called settlers, try to exercise control/authority over portions of land they had legitimately purchased, by enforcing tenancy-charges on indigenes using their land. The Isimkpuma motor park market allegedly owned by Ezza people are used by the Ezillo people for business but decline payment of tenancy-charges to Ezza who insist that they must pay. A phone booth entrepreneur in the market from Ezillo refuse to pay market toll to the Ezza toll collector and that led to the identity/authority struggle that escalated into a full blown intra-communal war protracting for over two years starting from $10^{\text {th }}$ May, 2008. The intervention of local and state authorities did not stop the war until the federal force came in to enforce order. The disputed portions of land have remained cordoned off from public access. This constitutes challenges to general economic activities and development.

Despite the promise of equitable distribution of land to all in the Land Use Act of 1978, the Act only succeeded in concentrating community land into private hands of the privileged few against the majority in need of land. ${ }^{23}$ That land ownership rights belonging to the state and few privileged individuals is never acceptable to the people. ${ }^{24}$ The indigenous communal land ownership structure was weakened by land reforms beginning from the colonial time with post-colonial reforms merely retaining the colonial structuring. The fact that this structure does not recognise indigenous authority particularly regarding land ownership speaks to the recurrent conflicts that characterise indigene/settler relations in most Nigerian communities.

Generally, land-related violent conflicts in most southern parts of Nigeria are either caused by identity-politics or authority/supremacy between indigenes and settlers. The climatic variation between the north and the south remains a major trigger of some of the conflicts. The perspective to conflict in Nigeria can be explained in the context of herders/farmers clash over land space, water, and vegetation, needed to farm and/or graze. As desertification, drought, and industrialisation intensify, there is influx of nomadic cattle

\footnotetext{
${ }^{22}$ S.A. Benjamin, 1999. The 1996 State and Local Government Reorganizations in Nigeria, Ibadan: NISER Monograph Series Number 21, pp. 17.

${ }^{23}$ G. B. Shedrack, E.I. Alamijeabee and B.S. Zainab, 1999. 'Communal Conflicts and the Possibilities of Conflict Resolution in Nigeria: A case study of the Tiv-Jukun Conflicts in Wukari Local Government Area, Taraba State', in O. Otite and I. O. Albert (eds). Community Conflicts in Nigeria: Management, Resolution and Transformation, Ibadan, Spectrum, p: 82-89.

${ }^{24}$ Ibeanu, Okechukwu 2000. "Oiling the friction: Environmental conflict management in the Niger Delta, Nigeria.” Environmental Change and Security Project Report, Number 6, pp. 19-32.
} 
herders to the south in search of water and grassland to feed their livestock. This migration interrupts agricultural intensification in the south as it results in several security problems.

\section{Seasonal Migration AND SECURity QUeStions in Nigeria}

Climate variation and its associated events such as migration, land scarcity, competition, dispossession, displacement and conflict are seasonal occurrences that are unpredictably debilitating to society and its security. While climatic variation is a natural occurrence, the events that accompany it are unfavorably human. These activities unfold with phenomenal impact on economic and social security and development. Failed attempts in the past to mitigate and constitutionally resolve these human factors have not succeeded because Nigerian constitution did not address them comprehensively. Consequent to constitutional lapses in solving these problems is the coinage of migration and security question in Nigeria. However, while many of the outcomes of this seasonal variation favour one part of Nigeria, other locations are unfavoured. For instance, while rainfall is heavy in the south, the north mostly experience draught. This implies that conflicts generated are interest based that need dialogue, understanding and compromise in the absence of constitutional prescriptions.

Considering the demographic strength of the Fulani people involved in nomadic pastoral farming will no doubt shade light on why their southward movement is phenomenally significant. Since the Fulani moved east into Nigeria in the $14^{\text {th }}$ century, they have increased to an estimated population of 18.7 million. ${ }^{25}$ Remarkably, the people have vigorously protected their culture to avoid adulteration. They have never given up on the one Nigeria project they consider as a big market for their huge animal production skill. To them, its only under one Nigeria that they can move with their livestock from place to place without restriction. With the increasing clamour by other federating units in Nigeria for an equitable restructuring of Nigeria to favour all and not just some, the Fulani is becoming more assertive than ever in the quest to hold on to political power as a tool for self-perpetuation.

The overwhelming rejection by states of the federal government request for donation of land for cattle colony and ranches is suggestive of the intrigues associated with Nigerian politics and the Fulani interest. Considering the political support network available to herders more than their counterpart farmers, it is becoming increasingly difficult or nearly impossible for pastoralist not to intensify their invasion of southern grassland for seasonal cattle grazing. According to one pastoralist from Plateau State:

The pastoralist invades our farms with such impunity that suggest deliberate intension to test our strength. Any attempt by our farmers to chase the cattle away leads to clandestine display of sophisticated weapons and ammunitions. This makes us believe that there are more to herders'

\footnotetext{
${ }^{25}$ Van Driel, A. 1999. The end of herding contract and decreasing complimentary linkages between Fullbe Pastoralists and Dendi Agriculturalists in Northern Benin. In V. Azarya et al (eds) Pastoralists under pressure. Leiden: Brill.
} 
invasion that meet the eyes. The extent of rampage chasing away cattle result to is incredible. It show how much value the herdsmen place on their cattle. ${ }^{26}$

An interviewee says:

Investment in agriculture is increasingly declining because of the activities of herdsmen and their cattle destroying farmland. Our youthful farmers who cannot stand the provocation have resorted to fight to chase cattle and their headers away from farmland. In fact, livelihood in Yobe State dominated by agrarian production is near zero as people are mostly fighting instead of farming to defend their farm produce and farmland from Fulani invaders. ${ }^{27}$

Also, another farmer from Enugu State says:

Cost of farm labour and food price has gone up here because of the risks involved in the regular Fulani herder's invasion of our farms regularly with their cow to destroy our farm produce. People are discouraged from going to farm to avoid the attack of herdsmen. Despite government and traditional interventions, the pastoralists have not stopped attacking farmers and their farm right inside the farm. ${ }^{28}$

The data above show that some pastoralists' social thought and cosmology reside the state of nature. This depicts him as a natural man who has no static home but makes everywhere his home. Contrasting this thought is their eagerness to protect their traditional culture and identity as pastoralists. However, the pastoralists strive to safeguard their economic interest in cattle rearing, the sedentary farmers are counting loses in farm input and output many of which are lost to cattle invasion of farmland. The implication of this is a shortfall in food production and food security across the country Nigeria. The government clamour for diversification from oil-based economy to agro-based economy is facing challenge of not only climate change but human challenges such as herders/farmers clash and it resultant restriction of agricultural production and productivity. Youths and rural peasants are discouraged from going to farm or investing in farming for fear of crop destruction by herder's cattle and conflict. Since there are limited government subsidies on food product or its production with its inequitable distribution, only the privileged few access inputs such as seedlings and manure fertilizer for farming. Consequently, the cost of product and production is forced up.

\section{Conclusion}

Overall, this paper explored the issue of environment and conflict linkages in Nigeria. It is a topical issue which is at the heart of Nigeria's current security challenge

\footnotetext{
${ }^{26} \mathrm{KII} /$ Male farmer/Lantan Village/ ${ }^{\text {th }}$ June, 2016.

${ }^{27} \mathrm{KII} /$ Male farmer/ Tumsa Village/ $29^{\text {th }}$ April, 2016.

${ }^{28} \mathrm{IDI} /$ Male farmer/Uzouwani Village/ $27^{\text {th }}$ August, 2016.
} 
particularly between farmers and herders. Having dwelled on Climate Variation-Induced Migration, Land Conflicts, and Security Situation in Nigeria, irregular migration pattern of both nomadic pastoralist and sedentary farmers contact and conflict were exhaustively discussed. Findings show lack of common ground and unequal government recognition for both farmers that deepen animosity and pressure for recognition. Similarly, climate variation as natural component and farming for survival and conflict induced human displacement as well as family dislocation mobilise migration. The movement of this population brings them to contact with others. Absence of social support network among the displaced, obstruct social control that make crime and conflict inevitable.

Drawing from the foregoing, it is recommended that policy be made to indigene, settlers and migrants in terms of what right each has over the other. Strategy to articulate and disseminate early warning information must evolve as legal framework.

Received: June, $6^{\text {th }} 2019$

Accepted: February, 13 ${ }^{\text {th }} 2020$ 